\title{
Dietary Reference Intakes for Japanese 2010: Fat-Soluble Vitamins
}

\author{
Kiyoshi TANAKA ${ }^{1}$, Junji TeraO ${ }^{2}$, Yoshihiro SHIDOJI ${ }^{3}$, Hiroshi TAMAI ${ }^{4}$, \\ Eri IMAI ${ }^{5}$ and Toshio OKANO ${ }^{6}$ \\ ${ }^{1}$ Department of Food and Nutrition, Kyoto Women's University, Kyoto 605-8501, Japan \\ ${ }^{2}$ Department of Food Science, Institute of Health Biosciences, The University of Tokushima \\ Graduate School, Tokushima 770-8503, Japan \\ ${ }^{3}$ Department of Nutrition and Health Science, Graduate School of Human Health Science, \\ University of Nagasaki, Nagasaki 851-2195, Japan \\ ${ }^{4}$ Department of Pediatrics, Osaka Medical College, Osaka 569-8686, Japan \\ ${ }^{5}$ Section of the Dietary Reference Intakes, Department of Nutritional Epidemiology, National Institute of \\ Health and Nutrition, Tokyo 162-8636, Japan \\ ${ }^{6}$ Department of Hygienic Sciences, Kobe Pharmaceutical University, Kobe, 658-8558, Japan
}

(Received October 26, 2012)

\begin{abstract}
Summary We have determined the Dietary Reference Intakes for fat-soluble vitamins (vitamin A, vitamin D, vitamin E, and vitamin K) for the Japanese. Regarding vitamin A, the estimated average requirement (EAR) and the recommended dietary allowance (RDA) were defined for those aged $1 \mathrm{y}$ old and over. For vitamin D, vitamin E, and vitamin $\mathrm{K}$, the EAR or RDA was not adopted, because of the insufficient data available. Thus, the adequate intake (AI) was determined for those vitamins based on the food surveillance data and biomarkers for each vitamin. The AI for vitamin D was decided as the median intake of vitamin D in the population with a circulating 25-hydroxy vitamin D level which was high enough for bone health. The basis for the AI for vitamin E was the median intake of $\alpha$-tocopherol in the healthy population considering the lack of unfavorable health consequences attributable to its deficiency. The AI for vitamin $\mathrm{K}$ was determined as the vitamin $\mathrm{K}$ intake, required to avoid blood coagulation abnormalities. The tolerable upper intake level (UL) was determined for vitamin A, vitamin D and vitamin E, but not for vitamin $\mathrm{K}$, since no adverse effects have been reported even with its high dosage.
\end{abstract}

Key Words vitamin A, vitamin D, vitamin E, vitamin K

\section{Vitamin A}

\section{Background information}

Compounds with potent vitamin A activity in vivo after oral intake include retinol; retinal; carotenoids; and 50 different types of provitamin A carotenoids, including $\beta$-carotene, $\alpha$-carotene, and $\beta$-cryptoxanthin. The retinol equivalent (RE) is the vitamin A unit used in Dietary Reference Intakes for Japanese (DRIs-J) 2010, the most current Dietary Reference Intakes (DRIs) for the Japanese. Retinoic acid, a hormone binding to the nuclear receptor, is responsible for the majority of vitamin A activity in vivo, but is not converted to retinal or retinol in vivo, and its content in food is relatively low. Retinylester provitamin A carotenoids are the main forms of vitamin A contained in animal and plant foods, respectively. Retinylester hydrolase in the intestinal brush border catalyzes the hydrolysis of retinylester to retinol, which is then absorbed at a rate that ranges from $70 \%$ to $90 \%(1,2)$. Cleavage of carotenoids yields 2 molecules of vitamin A (retinal) from $\beta$-carotene (3) and 1 molecule from other provitamin A carotenoids.

In the DRIs-J 2010, the absorption rate of $\beta$-carotene

E-mail: tanakak@kyoto-wu.ac.jp is $1 / 6$ of its total value, which is in accordance with rate in the DRIs for the United States and Canada (4). Assuming that the conversion rate of $\beta$-carotene to retinol is $50 \%$, the bioavailability of $\beta$-carotene as vitamin $\mathrm{A}$ is $1 / 12(1 / 6 \times 1 / 2)$, such that $12 \mu \mathrm{g}$ of food-derived $\beta$-carotene would correspond to $1 \mu \mathrm{g}$ in RE units. Thus, the following formula can be used to convert the value of food-derived vitamin A-related compounds into RE units:

Retinol equivalent ( $\mu \mathrm{g} \mathrm{RE})$

$=$ retinol $(\mu \mathrm{g})+\beta$-carotene $(\mu \mathrm{g}) \times 1 / 12$ $+\alpha$-carotene $(\mu \mathrm{g}) \times 1 / 24+\beta$-cryptoxantin $(\mu \mathrm{g})$

$\times 1 / 24+$ other provitamin A carotenoids $(\mu \mathrm{g})$

$\times 1 / 24$.

A word of caution is indicated when calculating the value for oil-solubilized $\beta$-carotene, as its bioavailability as a form of vitamin $A$ is $1 / 2$ of its total value, such that $2 \mu \mathrm{g}$ of fat-solubilized $\beta$-carotene would correspond to $1 \mu \mathrm{g}$ of retinol.

Determining DRIs

Classical vitamin A deficiency leads to corneal xerosis in infants and possibly to blindness and to night blindness in adults. Other deficiency signs include growth retardation; skeletal and neurological development defects; disturbed growth and differentiation of epi- 
thelial cells; dryness, thickening, and keratinization of the skin; immunodeficiency; and susceptibility to infection (5). Due to the abundant storage of vitamin A in the liver, inadequate intake does not lead to decreased plasma retinol concentration unless hepatic vitamin A storage is below $20 \mu \mathrm{g} / \mathrm{g}(6,7)$. Thus, plasma retinol concentration cannot be used as an index of vitamin A status. Theoretically, hepatic vitamin A storage is the best index, but its measurement is highly invasive and not applicable to humans. Thus, the vitamin A intake required to maintain minimal hepatic vitamin A storage has been used for estimating the Estimated Average Requirement (EAR) for vitamin A.

Compartment analysis assuming the existence of 3 compartments - serum, liver, and other tissueshas shown that the daily disposal rate of vitamin $\mathrm{A}$ is approximately $2 \%(8,9)$. Using this percentage, the daily disposal amount (DDA), daily disposal rate (DDR), body storage (BS) according to body weight (BW), and hepatic storage (HS) of vitamin A can be calculated as follows:

$$
\begin{aligned}
& \text { DDA }(\mu \mathrm{g} / \mathrm{d})=\mathrm{BS}(\mu \mathrm{g}) \times \operatorname{DDR}(2 \% / \mathrm{d}(10)) . \\
& \mathrm{BS} / \mathrm{BW}(\mu \mathrm{g} / \mathrm{kg} \mathrm{BW}) \\
& =\mathrm{HS}(\geq 20 \mu \mathrm{g} / \mathrm{g}) \times \text { liver weight/BW }(21 \mathrm{~g} / \mathrm{kg} \mathrm{BW}) \\
& \quad \times 10 / 9,
\end{aligned}
$$

where $90 \%$ of the body storage of vitamin $\mathrm{A}$ is in the liver $(10,11)$.

$\mathrm{DDA} / \mathrm{BW}(\mu \mathrm{g} /[\mathrm{kg} \mathrm{BW} \cdot \mathrm{d}])$

$=\mathrm{BS}(\geq 20 \mu \mathrm{g} / \mathrm{g} \times 21 \mathrm{~g} / \mathrm{kg} \times 10 / 9) \times \mathrm{DDR}(2 / 100)$

$=9.3 \mu \mathrm{g} / \mathrm{kg} \mathrm{BW}$.

Thus, the amount of vitamin A intake required to compensate for its daily elimination, thereby ensuring that hepatic storage of vitamin $\mathrm{A}$ is maintained and vitamin A deficiency is avoided, is estimated to be $9.3 \mu \mathrm{g}$ $\mathrm{RE} / \mathrm{kg} \mathrm{BW/d}$.

EAR and Recommended Dietary Allowance (RDA) for adults

The EAR for vitamin A for those aged $18 \mathrm{y}$ and above, as calculated by multiplication of the reference value of $9.3 \mu \mathrm{g} \mathrm{RE} / \mathrm{kg} \mathrm{BW} / \mathrm{d}$ and the reference $\mathrm{BW}$, is 550 to $600 \mu \mathrm{g} \mathrm{RE} / \mathrm{d}$ for males and 450 to $500 \mu \mathrm{g} \mathrm{RE} / \mathrm{d}$ for females. Assuming the inter-individual variability in vitamin A requirement to be $20 \%$ (4), multiplication of these EAR values by 1.4 yields an RDA of 800 to $850 \mu \mathrm{g}$ $\mathrm{RE} / \mathrm{d}$ for males and 650 to $700 \mu \mathrm{g}$ RE/d for females.

EAR and RDA for children

The RDA for children aged 6 to $17 \mathrm{y}$ was determined by extrapolation from the EAR for adults aged 18 to $29 \mathrm{y}$ by the 0.75 th power of the BW ratio, which represents the ratio of body surface area (4). Extrapolation of the adult EAR to preschool children based on BW ratio may yield values that maintain plasma retinol levels below $20 \mu \mathrm{g} / 100 \mathrm{~mL}$, and thus render children susceptible to corneal xerosis (12). Therefore, the RDA for children aged less than 5 y must be at least $200 \mu \mathrm{g}$ RE/d to avoid this unfavorable outcome; therefore, for children aged less than $5 \mathrm{y}$, the DDA was calculated as follows, assuming the ratio of liver weight/BW to be $42 \mathrm{~g} / \mathrm{kg} \mathrm{BW}(10)$ :

$\mathrm{DDA} / \mathrm{BW}(\mu \mathrm{g} / \mathrm{kg} \mathrm{BW} / \mathrm{d})$

$=\mathrm{BS}(\geq 20 \mu \mathrm{g} / \mathrm{g} \times 42 \mathrm{~g} / \mathrm{kg} \times 10 / 9) \times \mathrm{DDR}(2 / 100)$

$=18.7 \mu \mathrm{g} / \mathrm{kg} \mathrm{BW}$.
Using the value obtained, the EAR for children aged 1 to 5 y was calculated as follows:

$\mathrm{EAR}=18.7 \mu \mathrm{g} / \mathrm{kg} \mathrm{BW} / \mathrm{d} \times$ reference $\mathrm{BW} \times(1+$ growth factor) $=\mathrm{EAR} \times 1.4$.

Adequate Intake of infants aged 0 to $5 \mathrm{mo}$

Vitamin A concentration in breast milk is highest during the first $10 \mathrm{~d}$ after delivery, after which it gradually decreases $(13,14)$. Based on the values for average vitamin A concentration (411 $\mu \mathrm{g}$ RE/L) (14) and daily milk intake $(0.78 \mathrm{~L} / \mathrm{d})(15,16)$, vitamin $\mathrm{A}$ intake in breast milk-fed infants aged 0 to 5 mo was estimated at $320 \mu \mathrm{g}$ $\mathrm{RE} / \mathrm{d}$. Thus, adequate intake (AI) for this age group was determined to be $300 \mu \mathrm{g} / \mathrm{d}$. The level of provitamin A carotenoids was not taken into account because its availability is unknown.

AI of infants 6 to $11 \mathrm{mo}$

Based on extrapolation from the AI for infants aged 0 to $5 \mathrm{mo}$, the AI for infants aged 6 to 11 mo was determined to be $400 \mu \mathrm{g} \mathrm{RE} / \mathrm{d}$. The level of provitamin A carotenoids was not taken into account because its availability is unknown.

Amount to be added during pregnancy

The amount of vitamin A transported to the fetus through the placenta must be taken into account when estimating the vitamin A requirement for pregnant women. At the late-stage of a fetus, the amount of vitamin A deposited in the fetal liver was $1,800 \mu \mathrm{g}(17,18)$ so that the total amount of vitamin A transported to the fetus during pregnancy is estimated at 3,600 $\mu \mathrm{g}$. Using this value, the EAR value for the additional amount of vitamin A required during the late stage was determined to be $60 \mu \mathrm{g} \mathrm{RE} / \mathrm{d}$, which, assuming an interindividual variability of $20 \%$ (4), yielded an RDA value of $80 \mu \mathrm{g} \mathrm{RE} / \mathrm{d}$ during the late-stage. The additional amount required during the early- and mid-stage was not determined.

Amount to be added during lactation

Based on measurement of the amount of vitamin A secreted in breast milk, the EAR value for the additional amount of vitamin A required during lactation was estimated at $300 \mu \mathrm{g} \mathrm{RE} / \mathrm{d}$, which, assuming an interindividual variability of $20 \%$, yielded an RDA value of $450 \mu \mathrm{g} \mathrm{RE} / \mathrm{d}(4)$.

Tolerable upper intake level

An elevated plasma level of retinoic acid is considered responsible for most clinical signs (19) and symptoms of vitamin A intoxication, such as headache. Based on reported fetal abnormalities due to excessive intake of vitamin A, $(20,21)$ the no observable adverse effect level (NOAEL) during pregnancy was estimated at $4,500 \mu \mathrm{g} \mathrm{RE} / \mathrm{d}$, which, assuming an uncertainty factor of 1.5 and taking the additional amount into account, yielded an upper level (UL) of 3,000 $\mu \mathrm{g} \mathrm{RE/d.}$

Based on research into hepatotoxicity caused by the excessive vitamin A deposition (22), the NOAEL in adults was estimated at 13,500 $\mu \mathrm{g} \mathrm{RE/d,} \mathrm{which,} \mathrm{assum-}$ ing an uncertainty factor of 5 , yielded a UL of $2,700 \mu \mathrm{g}$ $\mathrm{RE} / \mathrm{d}$. Based on clinical observation of increased intracranial pressure in infants caused by excessive vitamin 
Table 1. DRIs for vitamin A $(\mu \mathrm{g} R E / \mathrm{d}){ }^{1}$

\begin{tabular}{|c|c|c|c|c|c|c|c|c|}
\hline \multirow{2}{*}{$\frac{\text { Sex }}{\text { Age }}$} & \multicolumn{4}{|c|}{ Males } & \multicolumn{4}{|c|}{ Females } \\
\hline & $\mathrm{EAR}^{2}$ & $\mathrm{RDA}^{2}$ & $\mathrm{AI}^{3}$ & $\mathrm{UL}^{3}$ & $\mathrm{EAR}^{2}$ & $\mathrm{RDA}^{2}$ & $\mathrm{AI}^{3}$ & $\mathrm{UL}^{3}$ \\
\hline $0-5 \mathrm{mo}$ & - & - & 300 & 600 & - & - & 300 & 600 \\
\hline $6-11 \mathrm{mo}$ & - & - & 400 & 600 & - & - & 400 & 600 \\
\hline $1-2 \mathrm{y}$ & 300 & 400 & - & 600 & 250 & 350 & - & 600 \\
\hline $3-5 y$ & 300 & 450 & - & 700 & 300 & 450 & - & 700 \\
\hline $6-7 \mathrm{y}$ & 300 & 450 & - & 900 & 300 & 400 & - & 900 \\
\hline $8-9 y$ & 350 & 500 & - & 1,200 & 350 & 500 & - & 1,200 \\
\hline 10-11 y & 450 & 600 & - & 1,500 & 400 & 550 & - & 1,500 \\
\hline $12-14 \mathrm{y}$ & 550 & 750 & - & 2,000 & 500 & 700 & - & 2,000 \\
\hline $15-17 \mathrm{y}$ & 650 & 900 & - & 2,500 & 450 & 650 & - & 2,500 \\
\hline $18-29 \mathrm{y}$ & 600 & 850 & - & 2,700 & 450 & 650 & - & 2,700 \\
\hline $30-49 y$ & 600 & 850 & - & 2,700 & 500 & 700 & - & 2,700 \\
\hline $50-69$ y & 600 & 850 & - & 2,700 & 500 & 700 & - & 2,700 \\
\hline$\geq 70 \mathrm{y}$ & 550 & 800 & - & 2,700 & 450 & 650 & - & 2,700 \\
\hline \multicolumn{9}{|l|}{$\begin{array}{l}\text { Pregnant women } \\
\text { (amount to be added) }\end{array}$} \\
\hline Early-stage & & & & & +0 & +0 & - & - \\
\hline Mid-stage & & & & & +0 & +0 & - & - \\
\hline Late-stage & & & & & +60 & +80 & - & - \\
\hline $\begin{array}{l}\text { Lactating women } \\
\text { (amount to be added) }\end{array}$ & & & & & +300 & +450 & - & - \\
\hline
\end{tabular}

DRIs, Dietary Reference Intakes; RE, retinol equivalents; EAR, estimated average requirement; RDA, recommended dietary allowance; AI, adequate intake; UL, tolerable upper intake level.

${ }^{1}$ Retinol equivalent $(\mu \mathrm{g} \mathrm{RE})=$ retinol $(\mu \mathrm{g})+\beta$-carotene $(\mu \mathrm{g}) \times 1 / 12+\alpha$-carotene $(\mu \mathrm{g}) \times 1 / 24+\beta$-cryptoxanthin $(\mu \mathrm{g}) \times 1 / 24$

+ other provitamin A carotenoids $(\mu \mathrm{g}) \times 1 / 24$.

${ }^{2}$ Including provitamin A carotenoids.

${ }^{3}$ Excluding provitamin A carotenoids.

A intake (23), the NOAEL in infants was estimated at $6,000 \mu \mathrm{g} \mathrm{RE} / \mathrm{d}$, which, assuming an uncertainty factor of 10 , yielded a UL of $600 \mu \mathrm{g} \mathrm{RE} / \mathrm{d}$.

The UL for children aged 1 to $17 \mathrm{y}$ was determined by extrapolation from the UL for adults based on the ratio of body surface area. For safety reasons, the values for men were applied to women. Extrapolation to infants aged 1 to $2 \mathrm{y}$ old yielded a UL of $500 \mu \mathrm{g} \mathrm{RE} / \mathrm{d}$, which is lower than that for infants aged 6 to $11 \mathrm{mo}(600 \mu \mathrm{g}$ $\mathrm{RE} / \mathrm{d})$. Thus, the UL for infants aged 1 to $2 \mathrm{y}$ old was revised to $600 \mu \mathrm{g} \mathrm{RE} / \mathrm{d}$. Although a recent study found that ingesting approximately $1,500 \mu \mathrm{g} \mathrm{RE} / \mathrm{d}$ of retinol for $30 \mathrm{y}$ doubled the fracture risk in the elderly (24), data from other studies contradicted this finding. Thus, determination of a separate UL for vitamin A for the elderly was not considered in developing the most recent DRIs. Moreover, as excessive intake of $\beta$-carotene has not been reported to be associated with the unfavorable consequences of vitamin A intoxication described above, the level of provitamin A carotenoids was also not included in the estimation of UL.

Remarks regarding carotenoids

Due to the strict regulation of their conversion into vitamin A, provitamin A carotenoids, when ingested orally, cannot cause vitamin A intoxication. Unconverted provitamin A carotenoids, as well as carotenoids that are not metabolized to vitamin A are stored in vivo as they are. Beneficial actions have been reported with ingestion of these carotenoids, including anti-oxidant activity and immune potentiation and photoprotection of skin by anti-oxidation. Regarding the benefits of specific carotenoids, prevention of prostate cancer by lycopene, improvement in age-related macular degeneration by lutein and zeaxanthin, and the maintenance of retinal pigment by lutein and zeaxanthin have also been reported. Although the results of cohort studies suggest that higher intake of carotenoids is associated with lower incidence of lung cancer (25), supplementary intervention has been reported to be ineffective or even harmful in the prevention of cancer, especially lung cancer (26-29). Thus, further research into the efficacy and safety of carotenoids is required. In developing the current DRIs, the carotenoids were not separately considered because their deficiency has not been reported.

DRI values for vitamin A are listed in Table 1.

\section{Vitamin D}

\section{Background information}

Vitamin $\mathrm{D}_{2}$ and vitamin $\mathrm{D}_{3}$ are naturally occurring compounds with potent vitamin $\mathrm{D}$ activity. The indices for the DRI of vitamin D is based on the summation of the values of these 2 compounds. The human body obtains vitamin D from 2 sources. One is exposure to ultraviolet irradiation, which converts pro-vitamin $\mathrm{D}_{3}$ 
(7-dehydrocholesterol) in the skin to pre-vitamin $\mathrm{D}_{3}$, which in turn is converted into vitamin $\mathrm{D}_{3}$ by thermal isomerization. The other is dietary intake of vitamin $\mathrm{D}_{2}$ and vitamin $\mathrm{D}_{3}$ from such sources as mushrooms and fish; good sources for vitamin $\mathrm{D}_{2}$ and vitamin $\mathrm{D}_{3}$, respectively. The current DRIs do not discriminate between vitamin $\mathrm{D}_{2}$ and $\mathrm{D}_{3}$ intake because the compounds have similar characteristics and a similar molecular weight and exert an almost equal level of biological activity.

Vitamin D is first metabolized to 25-hydroxy vitamin $\mathrm{D}(25 \mathrm{OHD})$ before being metabolized to $1 \alpha, 25$-dihydroxy vitamin $\mathrm{D}\left(1 \alpha, 25(\mathrm{OH})_{2} \mathrm{D}\right)$, its active form. Major actions of vitamin $\mathrm{D}$ include enhancing the absorption of calcium and phosphate in the intestine and kidneys and stimulating bone formation and growth. Circulating $250 \mathrm{HD}$ level is the best index of vitamin D status. As vitamin D deficiency and resultant hypocalcemia cause elevated levels of serum parathyroid hormone (PTH), serum concentration of PTH can also be a good index of vitamin D deficiency (30).

\section{Adequate intake}

Evidence for determining AI

Vitamin D deficiency impairs calcium absorption from the intestine and kidney, thus decreases calcium availability, resulting in rickets in children and osteomalacia in adults. In adults, especially the elderly, even so-called "vitamin D insufficiency," which is milder than vitamin D deficiency, can result in increased secretion of PTH, increased bone resorption, and decreased bone mineral density. Therefore, the basis for determining the vitamin $\mathrm{D}$ requirement is maintenance of a serum $250 \mathrm{HD}$ level sufficiently high to maintain normal calcium availability and avoid elevation of serum PTH level. Due to limitations on the data available, AI was determined as the median intake of vitamin $\mathrm{D}$ in a population in which the required circulating $250 \mathrm{HD}$ level is maintained.

\section{AI for adults}

In a study conducted in the northern United States, an area in which residents receive limited sunshine exposure, serum PTH level after vitamin D administration decreased in those with a serum $250 \mathrm{HD}$ level below $50 \mathrm{nmol} / \mathrm{L}$ but not in those with a level above $50 \mathrm{nmol} / \mathrm{L}$ (31). In a study in Niigata, those with a $250 \mathrm{HD}$ level less than $50 \mathrm{nmol} / \mathrm{L}$ had higher serum PTH levels and a higher prevalence of low bone mineral density (32). Based on consideration of these results, maintenance of a circulating $250 \mathrm{HD}$ level of at least $50 \mathrm{nmol} / \mathrm{L}$ is considered necessary to avoid elevation of serum PTH level and decrease in bone mineral density. In the study conducted in the northern United States, serum PTH level exhibited seasonal variation, reaching a nadir between August and October and a peak between March and May. However, this variation was not observed in those taking $5.5 \mu \mathrm{g} / \mathrm{d}$ or more of vitamin $\mathrm{D}$ (33), leading to the conclusion that taking at least $5.5 \mu \mathrm{g} / \mathrm{d}$ of vitamin $\mathrm{D}$ can prevent elevation of PTH in those living in areas in which they have limited sunshine exposure.

In 7 studies that examined Japanese women (34-39) aged 50 to $69 \mathrm{y}$, the average $250 \mathrm{HD}$ level was found to exceed $50 \mathrm{nmol} / \mathrm{L}$. In contrast, in several studies that examined women aged 18 to $29 \mathrm{y}(32,34)$ and women

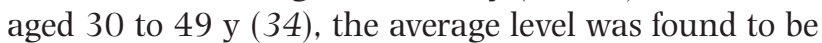
below $50 \mathrm{nmol} / \mathrm{L}$. Based on these findings and the findings from US studies, the median vitamin D intake of adults aged 50 to $69 \mathrm{y}$ was determined to be an appropriate basis for determining the adult AI. As the 2005 and 2006 National Health and Nutritional Survey (NHNS) $(40,41)$ found that the median intake of vitamin D in adults aged 50 to $69 \mathrm{y}$ was $5.5 \mu \mathrm{g} / \mathrm{d}$, the AI was set as $5.5 \mu \mathrm{g} / \mathrm{d}$. Due to lack of data for those aged 18 to $29 \mathrm{y}, 30$ to $49 \mathrm{y}$, and above $70 \mathrm{y}$, as well as lack of data for males, AI for both males and females in these age groups was also set at $5.5 \mu \mathrm{g} / \mathrm{d}$.

\section{AI for children}

As the findings regarding the relationship between vitamin D intake and plasma $250 \mathrm{HD}$ concentration in children have been inconsistent, they were considered unsuitable as the basis for determining the vitamin D AI for children. Thus, the median vitamin D intake, as reported in the 2005 and 2006 NHNS $(40,41)$, was used as the basis for determining the AI.

AI for infants

In an epidemiological study conducted in Kyoto, $22 \%$ of neonates were found to have craniotabes, a mineralization defect of bone, likely due to vitamin D deficiency (42). The incidence of craniotabes exhibited seasonal variation, with a peak and nadir between January and May and between July and November, respectively. Circulating 250HD level was found to be below $25 \mathrm{nmol} / \mathrm{L}$ in $37 \%$ of all neonates diagnosed with craniotabes at $1 \mathrm{mo}$ after birth. In breast milk-fed neonates, serum concentration of $250 \mathrm{HD}$ was found to be less than $25 \mathrm{nmol} / \mathrm{L}$ in $57 \%$ of subjects and below $12.5 \mathrm{nmol} / \mathrm{L}$ in $17 \%$. In contrast, none of the formula or mixed-fed infants were found to have an inadequate serum $250 H D$ level. It should be noted that neonates born in a vitamin D-deficient state may not recover to a vitamin D-sufficient state within a short period, and that the serum $250 \mathrm{HD}$ level of breast milk-fed infants was found to decrease further during the winter months (43), indicating that the vitamin D delivered from breast milk may have been unsatisfactory. The vitamin D AI for infants was determined to be $2.5 \mu \mathrm{g} / \mathrm{d}$ by multiplying $0.78 \mathrm{~L} / \mathrm{d}(15,16)$, the average daily milk intake, by $3.05 \mu \mathrm{g} / \mathrm{L}(44)$, the vitamin D concentration in breast milk as reported in the Standard Tables of Food Composition in Japan, 5th Revised and Enlarged Edition.

However, this AI value is appropriate only for infants with adequate sun exposure, defined as $2 \mathrm{~h} / \mathrm{wk}$ to the face or $30 \mathrm{~min} /$ wk to the face and extremities. Breastmilk-fed infants with little sun exposure are at higher risk of developing rickets. Considering that previous research found that no infants developed rickets after supplementation with $2.5 \mu \mathrm{g} / \mathrm{d}$ of vitamin $\mathrm{D}$ for 6 mo and assuming that infants receive an average of $2.38 \mu \mathrm{g} / \mathrm{d}$ of vitamin D from breast milk, it follows that a daily intake of $4.88 \mu \mathrm{g} / \mathrm{d}$ of vitamin D is satisfactory for avoiding rickets. Based on these data, the AI of vitamin D for infants aged 0 to 5 mo with limited sun exposure was determined to be $5 \mu \mathrm{g} / \mathrm{d}$. Recently, however, a 
Table 2. DRIs for vitamin D $(\mu \mathrm{g} / \mathrm{d})$.

\begin{tabular}{|c|c|c|c|c|c|c|c|c|}
\hline \multirow{2}{*}{$\begin{array}{l}\text { Sex } \\
\text { Age }\end{array}$} & \multicolumn{4}{|c|}{ Males } & \multicolumn{4}{|c|}{ Females } \\
\hline & EAR & $\mathrm{RDA}$ & AI & UL & EAR & $\mathrm{RDA}$ & AI & UL \\
\hline $0-5 \mathrm{mo}^{1}$ & - & - & $2.5(5.0)$ & 25 & - & - & $2.5(5.0)$ & 25 \\
\hline $6-11 \mathrm{mo}^{1}$ & - & - & $5.0(5.0)$ & 25 & - & - & $5.0(5.0)$ & 25 \\
\hline $1-2 \mathrm{y}$ & - & - & 2.5 & 25 & - & - & 2.5 & 25 \\
\hline $3-5 y$ & - & - & 2.5 & 30 & - & - & 2.5 & 30 \\
\hline $6-7 y$ & - & - & 2.5 & 30 & - & - & 2.5 & 30 \\
\hline $8-9 \mathrm{y}$ & - & - & 3.0 & 35 & - & - & 3.0 & 35 \\
\hline $10-11 \mathrm{y}$ & - & - & 3.5 & 35 & - & - & 3.5 & 35 \\
\hline $12-14 \mathrm{y}$ & - & - & 3.5 & 45 & - & - & 3.5 & 45 \\
\hline $15-17 \mathrm{y}$ & - & - & 4.5 & 50 & - & - & 4.5 & 50 \\
\hline $18-29 \mathrm{y}$ & - & - & 5.5 & 50 & - & - & 5.5 & 50 \\
\hline $30-49 \mathrm{y}$ & - & - & 5.5 & 50 & - & - & 5.5 & 50 \\
\hline $50-69 \mathrm{y}$ & - & - & 5.5 & 50 & - & - & 5.5 & 50 \\
\hline$\geq 70 \mathrm{y}$ & - & - & 5.5 & 50 & - & - & 5.5 & 50 \\
\hline $\begin{array}{l}\text { Pregnant women } \\
\text { (amount to be added) }\end{array}$ & & & & & - & - & +1.5 & - \\
\hline $\begin{array}{l}\text { Lactating women } \\
\text { (amount to be added) }\end{array}$ & & & & & - & - & +2.5 & - \\
\hline
\end{tabular}

${ }^{1}$ Adequate intakes for an infant who is exposed to appropriate sunlight. The value in parentheses is adequate intakes for those with less sunlight exposure.

study using a novel, highly accurate procedure found the average vitamin $\mathrm{D}$ concentration in breast milk to be only $0.6 \mu \mathrm{g} / \mathrm{L}$ (14). If this value is employed, the average vitamin D intake of breast-milk-fed infants would be only $0.47 \mu \mathrm{g} / \mathrm{d}$. Such discrepancies indicate the need for further research into this value $(45,46)$.

AI for infants aged 6 to $11 \mathrm{mo}$

The AI of vitamin D for infants aged 6 to 11 mo with adequate sun exposure was determined to be $5 \mu \mathrm{g} / \mathrm{d}$. This value was also applied to infants aged 6 to 11 mo with limited sun exposure due to lack of evidence for determining the AI.

Additional amount during pregnancy

In a study of pregnant women with limited sun exposure, an inadequate serum $250 \mathrm{HD}$ concentration was observed in those with an average vitamin D intake of less than $5.3 \mu \mathrm{g} / \mathrm{d}$ but not in those an average (47) vitamin D intake higher than $7 \mu \mathrm{g} / \mathrm{d}$ (48). As these findings indicate that pregnant women require at least $7 \mu \mathrm{g} / \mathrm{d}$ of vitamin $\mathrm{D}$, the additional amount of vitamin $\mathrm{D}$ required for pregnant women was determined to be $1.5 \mu \mathrm{g} / \mathrm{d}$. Additional amount during lactation

Based on the findings described above, the additional amount of vitamin D required for lactating women was determined to be $2.5 \mu \mathrm{g} / \mathrm{d}$.

Tolerable upper untake level

\section{Basic considerations}

Prolonged intake of excessive quantities of vitamin D can lead to unfavorable outcomes, such as hypercalcemia, renal dysfunction, soft tissue calcification, and growth retardation. As an increased serum 250HD level itself does not directly cause health problems, the presence of hypercalcemia rather than of a high serum $250 \mathrm{HD}$ level is considered an appropriate indicator for determining the UL.

UL for adults

In an intervention study administering doses of vitamin D for 3 mo, serum calcium concentration was found to exceed the reference value in some subjects receiving $95 \mu \mathrm{g} / \mathrm{d}$ of vitamin D but not in those receiving $60 \mu \mathrm{g} / \mathrm{d}$ of vitamin D (49). Thus, the lowest observed adverse effect level (LOAEL) and NOAEL were determined to be $95 \mu \mathrm{g} / \mathrm{d}$ and $60 \mu \mathrm{g} / \mathrm{d}$, respectively. The latter value was divided by an uncertainty factor of 1.2 yielding a UL for adults of $50 \mu \mathrm{g} / \mathrm{d}$. Since neither administration of $45 \mu \mathrm{g} / \mathrm{d}$ of vitamin D to elderly subjects for 3 mo (50) nor administration of $50 \mu \mathrm{g} / \mathrm{d}$ to pregnant and lactating subjects (51) was found to be associated with hypercalcemia, stratification by sex or age group was not performed, and a UL of $50 \mu \mathrm{g} / \mathrm{d}$ was applied to all adult groups.

UL for infants

Based on a study that observed no growth retardation in infants administered an average of $44 \mu \mathrm{g} / \mathrm{d}$ of vitamin D for 6 mo, the NOAEL for infants was determined to be $44 \mu \mathrm{g} / \mathrm{d}$ (52), which, assuming an uncertainty factor of 1.8 , yielded a UL of $25 \mu \mathrm{g} / \mathrm{d}$.

\section{UL for children}

As data were unavailable for this age group, the UL for children was determined by extrapolating the UL values for adults $(50 \mu \mathrm{g} / \mathrm{d})$ and infants $(25 \mu \mathrm{g} / \mathrm{d})$ based on the reference body weight. Sex differences were not considered.

DRI values for vitamin D are listed in Table 2.

\section{Vitamin E}

\section{Background information}

Vitamin $\mathrm{E}$ is composed of 8 analogues: $\alpha-, \beta-, \gamma$ - and 
Table 3. DRIs for vitamin $\mathrm{E}(\mathrm{mg} / \mathrm{d}){ }^{1}$

\begin{tabular}{|c|c|c|c|c|c|c|c|c|}
\hline \multirow{2}{*}{$\begin{array}{l}\text { Sex } \\
\text { Age }\end{array}$} & \multicolumn{4}{|c|}{ Males } & \multicolumn{4}{|c|}{ Females } \\
\hline & EAR & $\mathrm{RDA}$ & $\mathrm{AI}$ & UL & EAR & $\mathrm{RDA}$ & AI & UL \\
\hline $0-5 \mathrm{mo}$ & - & - & 3.0 & - & - & - & 3.0 & - \\
\hline $6-11 \mathrm{mo}$ & - & - & 3.5 & - & - & - & 3.5 & - \\
\hline $1-2 \mathrm{y}$ & - & - & 3.5 & 150 & - & - & 3.5 & 150 \\
\hline $3-5 y$ & - & - & 4.5 & 200 & - & - & 4.5 & 200 \\
\hline $6-7 y$ & - & - & 5.0 & 300 & - & - & 5.0 & 300 \\
\hline $8-9 \mathrm{y}$ & - & - & 6.0 & 350 & - & - & 5.5 & 350 \\
\hline $10-11 \mathrm{y}$ & - & - & 6.5 & 450 & - & - & 6.0 & 450 \\
\hline $12-14 \mathrm{y}$ & - & - & 7.0 & 600 & - & - & 7.0 & 600 \\
\hline $15-17 y$ & - & - & 8.0 & 750 & - & - & 7.0 & 650 \\
\hline $18-29 y$ & - & - & 7.0 & 800 & - & - & 6.5 & 650 \\
\hline $30-49 y$ & - & - & 7.0 & 900 & - & - & 6.5 & 700 \\
\hline $50-69 y$ & - & - & 7.0 & 850 & - & - & 6.5 & 700 \\
\hline$\geq 70 \mathrm{y}$ & - & - & 7.0 & 750 & - & - & 6.5 & 650 \\
\hline $\begin{array}{l}\text { Pregnant women } \\
\text { (amount to be added) }\end{array}$ & & & & & - & - & +0.0 & - \\
\hline $\begin{array}{l}\text { Lactating women } \\
\text { (amount to be added) }\end{array}$ & & & & & - & - & +3.0 & - \\
\hline
\end{tabular}

${ }^{1}$ Computation was made on $\alpha$-tocopherol, not including vitamins E other than $\alpha$-tocopherol.

$\delta$-forms, of tocopherol and tocotrienol. After intestinal absorption, vitamin $\mathrm{E}$ is packaged into chylomicron, transformed into chylomicron remnant by lipoprotein lipase, and transported to the liver. Of the 8 analogues, only $\alpha$-tocopherol is preferentially bound to $\alpha$-tocopherol binding protein, whereas the other analogues are metabolized in the liver. Alpha-tocopherol is then formed into very low-density lipoprotein (VLDL), converted into low-density lipoprotein (LDL), and distributed to various tissues (53). Due to these metabolic processes, $\alpha$-tocopherol constitutes the predominant vitamin $\mathrm{E}$ analogues present in the blood and various tissues. Based on these facts, only $\alpha$-tocopherol was considered when determining the current DRI for vitamin E.

Determining DRI

Basis for determining $A I$

Erythrocytes are susceptible to hemolysis by hydrogen peroxide when the circulating $\alpha$-tocopherol level is between 6 and $12 \mu \mathrm{mol} / \mathrm{L}$ (54), but resistant to it when the serum $\alpha$-tocopherol level is higher than $14 \mu \mathrm{mol} / \mathrm{L}$ (55). Although the data from an intervention study that administered graded doses of vitamin E to vitamin E-deficient subjects are available (56), they were not considered appropriate for estimating the EAR and RDA because they were collected many years ago. Several studies that simultaneously studied vitamin E intake and serum $\alpha$-tocopherol level consistently reported that the average serum $\alpha$-tocopherol level exceeded $22 \mu \mathrm{mol} / \mathrm{L}$ in all study populations (40, 41, 57-59). Average vitamin $\mathrm{E}$ intake in these studies ranged from 5.6 to $11.1 \mathrm{mg} / \mathrm{d}$, a range that encompasses the 2005 and 2006 NHNS values $(40,41)$ of an average vitamin E intake of $7.0 \mathrm{mg} / \mathrm{d}$ in men and $6.5 \mathrm{mg} / \mathrm{d}$ in women. As these findings indicate that the median intake of the
Japanese likely yields an adequate vitamin E status, the AI was determined to be the 2005 and 2006 NHNS median values stratified by sex and age group $(40,41)$. AI for adults

As described above, AI was determined to be the 2005 and 2006 NHNS median values for those aged 18 to 29 y stratified by sex and age group, specifically $7.0 \mathrm{mg} / \mathrm{d}$ for men and $6.5 \mathrm{mg} / \mathrm{d}$ for women, as these values are expected to yield a blood $\alpha$-tocopherol level exceeding $12 \mu \mathrm{mol} / \mathrm{L}(40,41)$. As aging has not been reported to be associated with compromised absorption or utilization of vitamin $\mathrm{E}$, the same values were applied to the elderly.

AI for children

The 2005 and 2006 NHNS median values for children stratified by sex and age group were used as the basis for determining the AI for children, as they had been for adults.

AI for infants aged $O$ to $5 \mathrm{mo}$

The AI for infants aged 0 to 5 mo was determined to be $3.0 \mathrm{mg} / \mathrm{d}$ by multiplying the average $\alpha$-tocopherol concentration in breast milk $(3.5$ to $4.0 \mathrm{mg} / \mathrm{L})(14,60)$ by the average milk intake $(0.78 \mathrm{~L} / \mathrm{d})(15,16)$.

AI for infants aged 6 to $11 \mathrm{mo}$

The AI for infants aged 6 to 11 mo old was determined to be $3.5 \mathrm{mg} / \mathrm{d}$ by extrapolation from the adult value by the 0.75 th power of the BW ratio.

AI during pregnancy

The AI for pregnant women was determined to be the same as that for non-pregnant women because vitamin E deficiency during pregnancy has not been reported.

Additional amount during lactation

Since the average $\alpha$-tocopherol content provided in breast milk is approximately $3.0 \mathrm{mg} / \mathrm{d}(14,60)$, the AI 
during lactation was determined to be $3 \mathrm{mg} / \mathrm{d}$.

Tolerable upper intake level

The basis for determining the UL for vitamin $\mathrm{E}$ is its possible effect on bleeding tendency. Based on the finding that supplementation with $800 \mathrm{mg} / \mathrm{d}$ of $\alpha$-tocopherol for $28 \mathrm{~d}$ did not increase bleeding tendency in healthy males (average body weight, $62.2 \mathrm{~kg}$ ) (61), the NOAEL was determined to be $800 \mathrm{mg} / \mathrm{d}$. Assuming an uncertainty factor of 1.0 and considering that no data regarding LOAEL are available, the sex- and age-group stratified UL was calculated by correcting the $800 \mathrm{mg} / \mathrm{d}$ value by $\mathrm{BW}$ ratio. Because few data are available regarding the UL for infants aged 0 to $11 \mathrm{mo}$ and because typical feeding with breast milk or baby food does not cause excessive intake, the UL was not determined for this age group.

Additional remarks

Although numerous intervention studies have examined the effect of vitamin $\mathrm{E}$ supplementation on the risk of coronary heart diseases, the findings have been inconsistent (62-65).

DRI values for vitamin $\mathrm{E}$ are listed in Table 3.

\section{Vitamin $K$}

\section{Basic considerations}

Naturally occurring vitamin K consists of phylloquinones (PKs; vitamin $\mathrm{K}_{1}$ ) and menaquinones (MKs; vita$\min \mathrm{K}_{2}$ ). Menaquinones are further subdivided into 11 analogues depending on the number of isoprene units (4-14) in the prenyl side chain. Among the menaquinones, of nutritional importance are menaquinone-4 (MK-4), which is ubiquitously present in animal foods, and menaquinone-7 (MK-7), which is abundantly present in natto, a traditional Japanese food made from soybeans fermented with Bacillus subtilis. At present, data are scarce for determining the relative biological activity of these analogues, and no corrections have been made for PK and MK-4 with similar molecular weights. MK-7, which has a much larger molecular weight, can be converted into its MK-4 equivalent using the following formula:

MK-4 equivalent $(\mathrm{mg})=\mathrm{MK}-7(\mathrm{mg}) \times 444.7 / 649$.

The sum of the quantity of PK, MK-4, and MK-7 as corrected above was employed in determining the DRI for vitamin K. Although long-chain MKs are produced by intestinal bacteria and MK-4 is also produced by enzymatic conversion from PK, their contribution was not considered sufficiently large to contribute to fulfilling this requirement. Although antibiotic treatment can impair vitamin $\mathrm{K}$ status by decreasing the production of MKs by intestinal flora and decreasing vitamin K utilization by inhibiting the enzymatic activity of vitamin $\mathrm{K}$ epoxide reductase (66), antibiotic treatment itself does not cause vitamin $\mathrm{K}$ deficiency if average vitamin $\mathrm{K}$ intake is maintained (67).

The principal biological action of vitamin $\mathrm{K}$ is activation of prothrombin and other serum coagulation factors, thereby enhancing blood coagulation. Other actions include the modulation of bone formation by activation of osteocalcin, a bone matrix protein, and inhibition of arterial calcification by activation of matrix gla protein (MGP), another vitamin-K-dependent matrix protein.

\section{Determining DRI}

\section{Evidence for determining AI}

Since delayed blood coagulation is the only clinically manifested abnormality attributable to vitamin K deficiency, the intake necessary to maintain normal serum coagulation was considered an appropriate basis for determining the AI for vitamin K. In Japan, however, coagulation abnormalities due to vitamin $\mathrm{K}$ deficiency are rarely observed in healthy subjects. An intervention study of young vitamin K-deficient male volunteers weighing $72 \mathrm{~kg}$ found that administration of 40 and $32 \mu \mathrm{g} / \mathrm{d}$ of vitamin resulted in a decrease in serum PK level and an elevation in undercarboxylated prothrombin, a serum marker for vitamin $\mathrm{K}$ deficiency, respectively, but that administration of $82 \mu \mathrm{g} / \mathrm{d}$ of vitamin $\mathrm{K}$ returned these levels to normal values (68). Based on these findings, the vitamin $\mathrm{K}$ requirement for healthy adults was determined to be approximately $1 \mu \mathrm{g} /[\mathrm{kg} \cdot \mathrm{d}]$.

Recent studies have suggested that skeletal vitamin $\mathrm{K}$ deficiency is a risk factor for fracture $(69,70)$, indicating that a much higher vitamin $\mathrm{K}$ intake is necessary for skeletal action. Although a recent meta-analysis found that vitamin $\mathrm{K}$ administration significantly reduced fracture incidence, it employed a high dosage $(45 \mathrm{mg} / \mathrm{d})$ of MK-4, which is considered to be pharmacological rather than nutritional (71). Based on the findings of previous research, a vitamin $\mathrm{K}$ intake of approximately $1.0 \mu \mathrm{g} /[\mathrm{kg} \cdot \mathrm{d}]$ was determined to be satisfactory to avoid even mild deficiency, and thus set as the AI for vitamin $\mathrm{K}$.

\section{AI for adults}

As described above, a vitamin $\mathrm{K}$ intake of $82 \mu \mathrm{g} / \mathrm{d}$ in those weighing $72 \mathrm{~kg}$ was found sufficient to avoid deficiency (68). Extrapolation of this value by the 0.75 th power of the BW ratio was used as the basis for determining the adult AI. Although the elderly may be more susceptible to vitamin $\mathrm{K}$ deficiency due to various factors such as impaired intestinal absorption of vitamin $\mathrm{K}$, at present, the data are scarce, and thus the AI for the elderly was the same as that for those aged 50 to $69 \mathrm{y}$. AI for children

The AI for children was determined by extrapolating the AI for adults by the 0.75 th power of the BW ratio. AI for infants aged 0 to $5 \mathrm{mo}$

Neonates are susceptible to vitamin $\mathrm{K}$ deficiency for various reasons, such as poor transplacental vitamin $\mathrm{K}$ transport (72), low vitamin $\mathrm{K}$ content in the breast milk $(14,73)$, or low production of vitamin $\mathrm{K}$ in the intestinal flora (74). As neonatal vitamin $\mathrm{K}$ deficiency is known to cause neonatal melena, a form of gastrointestinal bleeding, and intracranial bleeding, vitamin $\mathrm{K}$ is orally administered just after birth for their prevention. The AI of $4.0 \mu \mathrm{g} / \mathrm{d}$ for this age group was determined by multiplying the average milk intake $(0.78 \mathrm{~L} / \mathrm{d})$ by the average vitamin $\mathrm{K}$ content of milk $(5.17 \mu \mathrm{g} / \mathrm{L})$ and assuming oral administration of vitamin $\mathrm{K}$ just after birth in the clinical setting. 
Table 4. DRIs for Vitamin K ( $\mu \mathrm{g} / \mathrm{d})$.

\begin{tabular}{|c|c|c|c|c|c|c|c|c|}
\hline \multirow{2}{*}{$\begin{array}{l}\text { Sex } \\
\text { Age }\end{array}$} & \multicolumn{4}{|c|}{ Males } & \multicolumn{4}{|c|}{ Females } \\
\hline & EAR & $\mathrm{RDA}$ & $\mathrm{AI}$ & UL & EAR & $\mathrm{RDA}$ & AI & UL \\
\hline $0-5 \mathrm{mo}$ & - & - & 4 & - & - & - & 4 & - \\
\hline 6-11 mo & - & - & 7 & - & - & - & 7 & - \\
\hline $1-2 \mathrm{y}$ & - & - & 25 & - & - & - & 25 & - \\
\hline $3-5 y$ & - & - & 30 & - & - & - & 30 & - \\
\hline $6-7 y$ & - & - & 40 & - & - & - & 40 & - \\
\hline $8-9 y$ & - & - & 45 & - & - & - & 45 & - \\
\hline $10-11 \mathrm{y}$ & - & - & 55 & - & - & - & 55 & - \\
\hline $12-14 \mathrm{y}$ & - & - & 70 & - & - & - & 65 & - \\
\hline $15-17 \mathrm{y}$ & - & - & 80 & - & - & - & 60 & - \\
\hline $18-29 y$ & - & - & 75 & - & - & - & 60 & - \\
\hline $30-49$ y & - & - & 75 & - & - & - & 65 & - \\
\hline $50-69 y$ & - & - & 75 & - & - & - & 65 & - \\
\hline$\geq 70 \mathrm{y}$ & - & - & 75 & - & - & - & 65 & - \\
\hline $\begin{array}{l}\text { Pregnant women } \\
\text { (amount to be added) }\end{array}$ & & & & & - & - & +0 & - \\
\hline $\begin{array}{l}\text { Lactating women } \\
\text { (amount to be added) }\end{array}$ & & & & & - & - & +0 & - \\
\hline
\end{tabular}

\section{AI for infants aged 6 to $11 \mathrm{mo}$}

The AI was determined to be $7 \mu \mathrm{g} / \mathrm{d}$ by considering the amount of vitamin $\mathrm{K}$ received from sources other than breast milk.

\section{Additional amount during pregnancy}

Increased requirements for vitamin $\mathrm{K}$ or alterations in circulating vitamin $\mathrm{K}$ levels in pregnant women have not been reported. Because of poor transplacental transport, vitamin $\mathrm{K}$ intake in pregnant women is unlikely to affect vitamin $\mathrm{K}$ status in the fetuses or neonates. Thus, no additional amount required for pregnant women was determined.

\section{Additional amount during lactation}

Since lactating women have not been reported to be at higher risk for vitamin $\mathrm{K}$ deficiency, no additional amount required for lactating women was determined. Tolerable upper intake level

Although menadione, a vitamin $\mathrm{K}$ metabolite, can cause toxicity, no toxicity has been reported regarding PKs and MKs. As $45 \mathrm{mg} / \mathrm{d}$ of MK-4 is clinically administered to many patients in Japan with osteoporosis with no reports of serious adverse events, the UL for vitamin $\mathrm{K}$ was not determined.

\section{Other remarks}

Due to the abundant vitamin $\mathrm{K}$ content of natto, its intake is contraindicated in patients treated with warfarin. In contrast, patients undergoing long-term antibiotic treatment or experiencing chronic obstruction of the biliary tract or impaired fat absorption are at higher risk of vitamin K deficiency.

DRI values for vitamin K are listed in Table 4.

\section{REFERENCES}

1) Moise AR, Noy N, Palczewski K, Blaner WS. 2007. Delivery of retinoid-based therapies to target tissues. Bio- chemistry 46: 4449-4458.

2) Debier C, Larondelle Y. 2005. Vitamins A and E: metabolism, roles and transfer to offspring. Br J Nutr 93: $153-174$.

3) During A, Harrison EH. 2004. Intestinal absorption and metabolism of carotenoids: insights from cell culture. Arch Biochem Biophys 430: 77-88.

4) Food and Nutrition Board, Institute of Medicine. 2002. In: Dietary Reference Intakes for Vitamin A, Vitamin K, Arsenic, Boron, Chromium, Copper, Iodine, Iron, Manganese, Molybdenum, Nickel, Silicon, Vanadium and Zinc (Institute of Medicine, ed.), p 82-161. National Academy Press, Washington DC.

5) Sigmundsdottir H, Butcher EC. 2008. Environmental cues, dendritic cells and the programming of tissue-selective lymphocyte trafficking. Nat Immunol 9: 981-987.

6) Sauberlich HE, Hodges RE, Wallace DL, Kolder H, Canham JE, Hood J, Raica N Jr, Lowry LK. 1974. Vitamin A metabolism and requirements in the human studied with the use of labeled retinol. Vitam Horm 32: 251-275.

7) Ahmad SM, Haskell MJ, Raqib R, Stephensen CB. 2008. Men with low vitamin A stores respond adequately to primary yellow fever and secondary tetanus toxoid vaccination. J Nutr 138: 2276-2283.

8) Cifelli CJ, Green JB, Green MH. 2007. Use of model-based compartmental analysis to study vitamin A kinetics and metabolism. Vitam Horm 75: 161-195.

9) Furr HC, Green MH, Haskell M, Mokhtar N, Nestel P, Newton S, Ribaya-Mercado JD, Tang G, Tanumihardjo S, Wasantwisut E. 2005. Stable isotope dilution techniques for assessing vitamin A status and bioefficacy of provitamin A carotenoids in humans. Public Health Nutr 8: 596-607.

10) Cifelli CJ, Green JB, Wang Z, Yin S, Russell RM, Tang G, Green MH. 2008. Kinetic analysis shows that vitamin A disposal rate in humans is positively correlated with 
vitamin A stores. J Nutr 138: 971-977.

11) Raica N Jr, Scott J, Lowry L, Sauberlich HE. 1972. Vitamin A concentration in human tissues collected from five areas in the United States. Am J Clin Nutr 25: 291-296.

12) Joint FAO/WHO Expert Group. 2004. Vitamin A Human Vitamin and Mineral Requirements, 2nd ed, p 17-44. WHO/FAO, Geneva.

13) Canfield LM, Clandinin MT, Davies DP, Fernandez MC, Jackson J, Hawkes J, Goldman WJ, Pramuk K, Reyes H, Sablan B, Sonobe T, Bo X. 2003. Multinational study of major breast milk carotenoids of healthy mothers. Eur J Nutr 42: 133-141.

14) Kamao M, Tsugawa N, Suhara Y, Wada A, Mori T, Murata K, Nishino R, Ukita T, Uenishi K, Tanaka K, Okano T. 2007. Quantification of fat-soluble vitamins in human breast milk by liquid chromatography-tandem mass spectrometry. J Chromatogr B Analyt Technol Biomed Life Sci 859: 192-200.

15) Suzuki K, Sasaki S, Shinzawa K, Totani M. 2004. Milk intake by breast-fed infants before weaning. Jpn J Nutr Diet 62: 369-372 (in Japanese).

16) Hirose J, Endo M, Nagao S, Mizushima K, Narita H, Shibata K. 2008. Amount of breast milk sucked by Japanese breast feeding infants. J Jpn Soc Breastfeeding Res 2: 23-28 (in Japanese).

17) Montreewasuwat N, Olson JA. 1979. Serum and liver concentrations of vitamin A in Thai fetuses as a function of gestational age. Am J Clin Nutr 32: 601-606.

18) Strobel M, Tinz J, Biesalski HK. 2007. The importance of beta-carotene as a source of vitamin A with special regard to pregnant and breastfeeding women. Eur J Nutr 46 (Suppl 1): I1-20.

19) Penniston KL, Tanumihardjo SA. 2006. The acute and chronic toxic effects of vitamin A. Am J Clin Nutr 83: 191-201.

20) Azais-Braesco V, Pascal G. 2000. Vitamin A in pregnancy: requirements and safety limits. Am J Clin Nutr 71 (5 Suppl): 1325S-1333S.

21) Rothman KJ, Moore LL, Singer MR, Nguyen US, Mannino S, Milunsky A. 1995. Teratogenicity of high vitamin A intake. N Engl J Med 333: 1369-1373.

22) Minuk GY, Kelly JK, Hwang WS. 1988. Vitamin A hepatotoxicity in multiple family members. Hepatology 8 : 272-275.

23) Persson B, Tunell R, Ekengren K. 1965. Chronic vitamin a intoxication during the first half year of life; Description of 5 cases. Acta Paediatr Scand 54: 49-60.

24) Michaelsson K, Lithell H, Vessby B, Melhus H. 2003. Serum retinol levels and the risk of fracture. $N$ Engl $J$ Med 348: 287-294.

25) Männistö S, Smith-Warner SA, Spiegelman D, Albanes D, Anderson K, van den Brandt PA, Cerhan JR, Colditz G, Feskanich D, Freudenheim JL, Giovannucci E, Goldbohm RA, Graham S, Miller AB, Rohan TE, Virtamo J, Willett WC, Hunter DJ. 2004. Dietary carotenoids and risk of lung cancer in a pooled analysis of seven cohort studies. Cancer Epidemiol Biomarkers Prev 13: 40-48.

26) The Alpha-Tocopherol, Beta Carotene Cancer Prevention Study Group. 1994. The effect of vitamin E and beta carotene on the incidence of lung cancer and other cancers in male smokers. N Engl J Med 330: 1029-1035.

27) Albanes D, Heinonen OP, Taylor PR, Virtamo J, Edwards BK, Rautalahti M, Hartman AM, Palmgren J, Freedman LS, Haapakoski J, Barrett MJ, Pietinen P, Malila N, Tala
E, Liippo K, Salomaa ER, Tangrea JA, Teppo L, Askin FB, Taskinen E, Erozan Y, Greenwald P, Huttunen JK. 1996. Alpha-tocopherol and beta-carotene supplements and lung cancer incidence in the alpha-tocopherol, betacarotene cancer prevention study: effects of base-line characteristics and study compliance. J Natl Cancer Inst 88: $1560-1570$.

28) Omenn GS, Goodman GE, Thornquist MD, Balmes J, Cullen MR, Glass A, Keogh JP, Meyskens FL, Valanis B, Williams JH, Barnhart S, Hammar S. 1996. Effects of a combination of beta carotene and vitamin A on lung cancer and cardiovascular disease. N Engl J Med 334: 1150-1155.

29) Hennekens CH, Buring JE, Manson JE, Stampfer M, Rosner B, Cook NR, Belanger C, LaMotte F, Gaziano JM, Ridker PM, Willett W, Peto R. 1996. Lack of effect of long-term supplementation with beta carotene on the incidence of malignant neoplasms and cardiovascular disease. N Engl J Med 334: 1145-1149.

30) Holick MF. 2004. Vitamin D. In: Nutrition and Bone Health (Holick MF, Dawson-Hughes B, eds), p 403-440. Humana Press, Totowa, NJ.

31) Malabanan A, Veronikis IE, Holick MF. 1998. Redefining vitamin D insufficiency. Lancet 351: 805-806.

32) Nakamura K, Tsugawa N, Saito T, Ishikawa M, Tsuchiya Y, Hyodo K, Maruyama K, Oshiki R, Kobayashi R, Nashimoto M, Yoshihara A, Ozaki R, Okano T, Yamamoto M. 2008. Vitamin D status, bone mass, and bone metabolism in home-dwelling postmenopausal Japanese women: Yokogoshi Study. Bone 42: 271-277.

33) Krall EA, Sahyoun N, Tannenbaum S, Dallal GE, DawsonHughes B. 1989. Effect of vitamin D intake on seasonal variations in parathyroid hormone secretion in postmenopausal women. N Engl J Med 321: 1777-1783.

34) Nakamura K, Nashimoto M, Tsuchiya Y, Obata A, Miyanishi K, Yamamoto M. 2001. Vitamin D insufficiency in Japanese female college students: a preliminary report. Int J Vitam Nutr Res 71: 302-305.

35) Nakamura K, Nashimoto M, Matsuyama S, Yamamoto M. 2001. Low serum concentrations of 25-hydroxyvitamin D in young adult Japanese women: a cross sectional study. Nutrition 17: 921-925.

36) Nakamura K, Nashimoto M, Hori Y, Muto K, Yamamoto M. 1999. Serum 25-hydroxyvitamin D levels in active women of middle and advanced age in a rural community in Japan. Nutrition 15: 870-873.

37) Nakamura K, Nashimoto M, Yamamoto M. 2000. Summer/winter differences in the serum 25-hydroxyvitamin $\mathrm{D}_{3}$ and parathyroid hormone levels of Japanese women. Int J Biometeorol 44: 186-189.

38) Nakamura K, Nashimoto M, Hori Y, Yamamoto M. 2000. Serum 25-hydroxyvitamin D concentrations and related dietary factors in peri- and postmenopausal Japanese women. Am J Clin Nutr 71: 1161-1165.

39) Nakamura K, Nashimoto M, Yamamoto M. 2001. Are the serum 25-hydroxyvitamin D concentrations in winter associated with forearm bone mineral density in healthy elderly Japanese women? Int J Vitam Nutr Res 71: 25-29.

40) Ministry of Health Labour and Welfare, Japan. 2007. National Health and Nutritional Survey Japan (2005). Tokyo.

41) Ministry of Health Labour and Welfare, Japan. 2008. National Health and Nutritional Survey Japan (2006). Tokyo. 
42) Yorifuji J, Yorifuji T, Tachibana K, Nagai S, Kawai M, Momoi T, Nagasaka H, Hatayama H, Nakahata T. 2008. Craniotabes in normal newborns: the earliest sign of subclinical vitamin D deficiency. I Clin Endocrinol Metab 93: 1784-1788.

43) Nakao H. 1988. Nutritional significance of human milk vitamin D in neonatal period. Kobe J Med Sci 34: 121-128.

44) Ministry of Education, Culture, Sports, Science and Technology, Japan. 2005. Standard Tables of Food Composition in Japan, Fifth revised and enlarged ed, 2004. Tokyo.

45) Specker BL, Valanis B, Hertzberg V, Edwards N, Tsang RC. 1985. Sunshine exposure and serum 25-hydroxyvitamin D concentrations in exclusively breast-fed infants. J Pediatr 107: 372-376.

46) Specker BL, Ho ML, Oestreich A, Yin TA, Shui QM, Chen XC, Tsang RC. 1992. Prospective study of vitamin D supplementation and rickets in China. J Pediatr 120: 733-739.

47) MacLennan WJ, Hamilton JC, Darmady JM. 1980. The effects of season and stage of pregnancy on plasma 25-hydroxy-vitamin D concentrations in pregnant women. Postgrad Med J 56: 75-79.

48) Henriksen C, Brunvand L, Stoltenberg C, Trygg K, Haug E, Pedersen JI. 1995. Diet and vitamin D status among pregnant Pakistani women in Oslo. Eur J Clin Nutr 49: 211-218.

49) Narang NK, Gupta RC, Jain MK. 1984. Role of vitamin D in pulmonary tuberculosis. J Assoc Physicians India 32: 185-188.

50) Honkanen R, Alhava E, Parviainen M, Talasniemi S, Monkkonen R. 1990. The necessity and safety of calcium and vitamin D in the elderly. J Am Geriatr Soc 38: 862-866.

51) Ala-Houhala M, Koskinen T, Terho A, Koivula T, Visakorpi J. 1986. Maternal compared with infant vitamin D supplementation. Arch Dis Child 61: 1159-1163.

52) Fomon SJ, Younoszai MK, Thomas LN. 1966. Influence of vitamin D on linear growth of normal full-term infants. J Nutr 88: 345-350.

53) Traber MG, Arai H. 1999. Molecular mechanisms of vitamin E transport. Annu Rev Nutr 19: 343-355.

54) Horwitt MK, Century B, Zeman AA. 1963. Erythrocyte survival time and reticulocyte levels after tocopherol depletion in man. Am J Clin Nutr 12: 99-106.

55) Farrell PM, Bieri JG, Fratantoni JF, Wood RE, di Sant'Agnese PA. 1977. The occurrence and effects of human vitamin $\mathrm{E}$ deficiency. A study in patients with cystic fibrosis. J Clin Invest 60: 233-241.

56) Horwitt MK. 1960. Vitamin E and lipid metabolism in man. Am J Clin Nutr 8: 451-461.

57) Sasaki S, Ushio F, Amano K, Morihara M, Todoriki O, Uehara Y, Toyooka E. 2000. Serum biomarker-based validation of a self-administered diet history questionnaire for Japanese subjects. J Nutr Sci Vitaminol 46: 285-296.

58) Hiraoka M. 2001. Nutritional status of vitamin A, E, C, B1, B2, B6, nicotinic acid, B12, folate, and beta-carotene in young women. J Nutr Sci Vitaminol 47: 20-27.

59) Maruyama C, Imamura K, Oshima S, Suzukawa M, Egami S, Tonomoto M, Baba N, Harada M, Ayaori M, Inakuma T, Ishikawa T. 2001. Effects of tomato juice consumption on plasma and lipoprotein carotenoid concentrations and the susceptibility of low density lipoprotein to oxidative modification. J Nutr Sci Vitaminol 47:
213-221.

60) Sakurai T, Furukawa M, Asoh M, Kanno T, Kojima T, Yonekubo A. 2005. Fat-soluble and water-soluble vitamin contents of breast milk from Japanese women. $J$ Nutr Sci Vitaminol 51: 239-247.

61) Morinobu T, Ban R, Yoshikawa S, Murata T, Tamai H. 2002. The safety of high-dose vitamin E supplementation in healthy Japanese male adults. J Nutr Sci Vitaminol 48: 6-9.

62) Miller ER 3rd, Pastor-Barriuso R, Dalal D, Riemersma RA, Appel LJ, Guallar E. 2005. Meta-analysis: high-dosage vitamin E supplementation may increase all-cause mortality. Ann Intern Med 142: 37-46.

63) Bjelakovic G, Nikolova D, Gluud LL, Simonetti RG, Gluud C. 2007. Mortality in randomized trials of antioxidant supplements for primary and secondary prevention: systematic review and meta-analysis. JAMA 297: $842-857$.

64) Asleh R, Blum S, Kalet-Litman S, Alshiek J, Miller-Lotan R, Asaf R, Rock W, Aviram M, Milman U, Shapira C, Abassi Z, Levy AP. 2008. Correction of HDL dysfunction in individuals with diabetes and the haptoglobin 2-2 genotype. Diabetes 57: 2794-2800.

65) Milman U, Blum S, Shapira C, Aronson D, Miller-Lotan R, Anbinder Y, Alshiek J, Bennett L, Kostenko M, Landau M, Keidar S, Levy Y, Khemlin A, Radan A, Levy AP. 2008. Vitamin E supplementation reduces cardiovascular events in a subgroup of middle-aged individuals with both type 2 diabetes mellitus and the haptoglobin 2-2 genotype: a prospective double-blinded clinical trial. Arterioscler Thromb Vasc Biol 28: 341-347.

66) Frick PG, Riedler G, Brogli H. 1967. Dose response and minimal daily requirement for vitamin $\mathrm{K}$ in man. J Appl Physiol 23: 387-389.

67) Suttie JW. 1995. The importance of menaquinones in human nutrition. Annu Rev Nutr 15: 399-417.

68) Suttie JW, Mummah-Schendel LL, Shah DV, Lyle BJ, Greger JL. 1988. Vitamin K deficiency from dietary vitamin K restriction in humans. Am J Clin Nutr 47: 475-480.

69) Feskanich D, Weber P, Willett WC, Rockett H, Booth SL, Colditz GA. 1999. Vitamin K intake and hip fractures in women: a prospective study. Am J Clin Nutr 69: 74-79.

70) Booth SL, Tucker KL, Chen H, Hannan MT, Gagnon DR, Cupples LA, Wilson PW, Ordovas J, Schaefer EJ, DawsonHughes B, Kiel DP. 2000. Dietary vitamin K intakes are associated with hip fracture but not with bone mineral density in elderly men and women. Am J Clin Nutr $\mathbf{7 1}$ : 1201-1208.

71) Cockayne S, Adamson J, Lanham-New S, Shearer MJ, Gilbody S, Torgerson DJ. 2006. Vitamin K and the prevention of fractures: systematic review and meta-analysis of randomized controlled trials. Arch Intern Med 166: 1256-1261.

72) Shearer MJ, Rahim S, Barkhan P, Stimmler L. 1982. Plasma vitamin $\mathrm{K} 1$ in mothers and their newborn babies. Lancet 2: 460-463.

73) Kojima T, Asoh M, Yamawaki N, Kanno T, Hasegawa H, Yonekubo A. 2004. Vitamin K concentrations in the maternal milk of Japanese women. Acta Paediatr 93: $457-463$.

74) Greer FR, Mummah-Schendel LL, Marshall S, Suttie JW. 1988. Vitamin K1 (phylloquinone) and vitamin K2 (menaquinone) status in newborns during the first week of life. Pediatrics 81: 137-140. 